\title{
The Practice of Disclosing Sustainability Reports on Bank Performance: Maqashid Shariah Perspective
}

\author{
Arini $^{1 *}$ Satia Nur Maharani ${ }^{2}$ \\ ${ }^{1,2}$ Department of Accounting, Faculty of Economics and Business, State University of Malang, Indonesia \\ *Corresponding author. Email: aarin0814@gmail.com
}

\begin{abstract}
This study evaluated the correlation among the disclosure of sustainability report towards bank's performance from the perspective of Maqashid Syariah. Islamic Bank in Indonesia and Malaysia in the period of 2014-2018 was used as the sample in this study. The method used was Generalized Method Moments (GMM) with 4 model of research. As a result, this study showed that on the first (1) model (Diin) the variable of economic sustainability, social sustainability, and debt ratio have a significant positive impact toward Islamic banking perspective on religious maintenance. On the second (2) model (Maal) the variable of economic sustainability has a significant positive impact towards Islamic bank's performance and the perspective of preserving property. On the third (3) model (Nafs \& 'Aql) the variable of sustainability general standards and social sustainability have significant positive impact toward the preservation of main and soul. This finding implies that sustainability report was used as horizontal accountability (employee, community, and society). Further, on the fourth (4) model (Nasl) only the variable of social sustainability has significant positive impact toward perspective performance of raising descendent. Briefly, the result of this study shows that in the presentation of Islamic bank accountability implements Islamic objectives, namely rahmatan lil'alamin
\end{abstract}

Keywords: islamic bank's performance, maqashid syariah, sustainability report

\section{INTRODUCTION}

Climate change issue, threat of extinction of biodiversity, environmental pollution due to industrial waste, global warming that continue to increase as well as the land degradation challenges us to face that together [1]. In Indonesia, the spread of environmental damage increases significantly from year to year. The study conducted by Jamnbeck [2] shows that Indonesia is five biggest contributor that contaminate plastic garbage to the sea. Forest fires, floods, landslides, pollution and sedimentation, and the damage of the rivers have become the difficult problems to solve and prevent when economic interest deal with environment [3]. This has made a shift in business' perspective that is not only concerned with profit has become a trend lately, therefore it support the business organization to be more concern to the other factors such as social community and environmental conditions [4]

The continuality is needed in order to create the natural balance and human being, because the development that ignore each interaction causes expensive cost and imply on the decreasing number of people welfare [5]. Li \& Liu [6] stated that 3.000 companies from around the world had raised the cost of environmental externalities equal to loss with the amount of US\$2.5 trillion per year. Long \& Ji [7] studied in 31 provinces in China about inequality of opinion, long-term environmental damage and depletion of renewable sources using the Atkinson index. The result of the study shows that per capita income in some provinces is decreasing due to threats to social welfare and sustainability. 
The practical concept of sustainability now become a trend and challenge in all over industrial sectors, one of them is banking industry that slowly responds to this concept [8]. Global money crisis in 20072009 had shaken investor trust, and it impacts to the trust crisis towards banking systems that bring continuous issues about banking being global spotlight $[9,10,11]$. Banking, as the financial company, indirectly contribute to the environmental impact which raised as the effect from given financing or loans.

In banking industry case around the world, the sustainability report was found low. Gustani [12] found that based on the results of the index calculation analysis ISR towards general Islamic bank in Indonesia on the period of 2009-2011, the level of disclosure of social performance is still low. Further, Nobanee \& Ellili [13] discovered that the disclosure of Islamic bank sustainability was considered very low compared with conventional bank in United Arab Emirates. Based on Meutia \& Febrianti [14] study, the level of the disclosure of sustainability Islamic bank in Indonesia and Malaysia was only $26 \%$. As a result, the impact of low sustainability practice can worsen the financial performance of Islamic bank around the world. It is because of the positive correlation between sustainability practice and financial performance $[15,9,16]$.

To all this time, the financial ratio such as CAMEL, ROE, ROA, Tobins-Q dan BSC was used as the measurement of Islamic bank performance as if used in the research $[17,18,19,20]$. Based on the study conducted by Bedoi \& Mansour and Chapra [21,22] the measurement bank performance which focused on financial sector still has a weakness. Therefore, it needs to consider financial factor due to conduct a good measurement of bank performance. The effort to measure Islamic banking oriented to maqashid index can be used as the strategical, universal and comprehensive approach, because the scope of masaqih Syariah study covers all of life aspects [23].
Based on the empirical study above, it shows that the development achievements which rely on the principal study of sustainability not only gives an advantage to the earth, but also to the human benefit and business sustainability. Nonetheless, the analysis and measurement indicators are still become challenging factors in this sustainability context [5]. To date, the disclosure of Islamic banking sustainability activities is assessed based on the latest version of the Global Reporting Initiative (GRI) guideline indicators, namely G4 $[13,16]$.

According to Maji [24], it shows that the framework of Global Reporting Initiative is not adequate to publish business sustainability report. This measurement indicator of sustainability report is certainly not yet fully reflecting the highest goal of Islamic bank that is the benefit of the people. Consequently, it is needed to have a new innovation in order to create measurement indicator of sustainability practice in Islamic banking that based on maqasih Syariah. The study of Jan [9] tries to develop the measurement indicator of sustainability practice which synergized with the theory of maqasih Syariah.

The novelty of this study is regarding to the measurement of sustainability report used measurement standard of Global Reporting Initiative which synergized with the perspective of maqashid Syariah developed by Jan [9]. This study measures Islamic Banking performance used maqashid Syariah Index (MSI). It is believed that this index is suitable with the characteristics and philosophy of Islamic Banking, while the previous study used a benchmark which the same with conventional banking due to the lack of source of the proposed study. 


\section{LITERATUR REVIEW}

\subsection{Syariah Enterprise Theory}

Syariah Enterprise theory is a theory developed based on the zakat metaphor which is characterized by balance and provides fundamental implications for the concept of management and Islamic accounting [25]. According to Triyuwono [26], this theory is able to contain the plurality of stakeholders du to the underlying axiom in any establishment of the concept of Syariah enterprise theory is Allah SWT as the Creator and Sole Owner of all resources in this universe so that the use of these resources must be in accordance with His rules and regulations [27]

Syariah enterprise theory is the result of a selfreflection which is not only based on the benefits of ratio, but also spiritual value [28]. Triyuwono [25] stated that shariah enterprise theory views that the distribution of wealth or added value applies not only to those who contribute directly to the company but also to those who contribute to the non-financial sector.

According to Meutia [28] the right theory to reveal social responsibility in Islamic banks is the shariah enterprise theory, because this theory has the principle that the main form of accountability is to Allah (vertical accountability) then it is translated into the form of accountability to humans and nature (horizontal accountability) [29]. This idea is based on the premise that humans are Khalifatullah fil Ardh, who carries the mission of creating welfare for all creatures and all nature [30]. According to Triyuwono [25] that the final premise of this theory is falah, namely the essential success in business in the form of achieving spiritual and material welfare.

\subsection{Maqashid Syariah}

Auda [30] assumed that nowadays, Maqashid Syariah becomes one of the most intellectual methodology and medium for Islamic revolution. Maqashid Syariah as a methodology in Islam used to discuss about Islamic though and problem. Shinkafi, et. al [30] claimed that Maqashid Syariah becomes an instrument used to determine the compatibility of Islamic reform program in accordance with principles, objectives and values of Islamic law. Maqashid Syariah is a moral concept that becomes Islamic basic law, such as, justice, human dignity, generosity, and social cooperation. Therefore, Maqashid Syariah represents the correlation between Islamic law, human right, development and decency.

According to Imam Asy-Satibi, there are 5 (five) kinds of Maqashid Syariah [31,33,34,35]. The first, protection or maintains the religion (Hidz Ad-Din). This religion protection becomes the first aim of Islamic law. The second is protection or maintains the spirit (Hifdz An-Nafs). This maintenance is the second aim of Islamic law, hence, in this law, maintaining the human right to stay alive and take care of their life are required (Rauf, 2015). The third, the protection or maintains the intelligence ( $\mathrm{HifdzAl}^{\prime} A q \mathrm{l}$ ). Intelligence is a source of guidance (knowledge), ray of guidance and a medium to human happiness in the world and the life after [36,31] The fourth, the protection or maintains the wealth (Hifdz Al-Maal). Wealth becomes one of necessities that cannot be separated from our life $[37,34]$. The fifth, protection or maintains the descents (Hifdz An-Nasb). In Islam, maintaining the descents (nasb) through prohibition of adultery $[37,36]$.

\subsection{Hypothesis Development}

According to Triyuwono [25], Syariah enterprise theory shows Value-added Statement as one of the financial reports. This report shows the information about the value-added created by company and also the distribution of value-added to increase the commonweal. In 2009, Meutia [28] stated that financial institution needs to reveal social responsibility, in accordance to concept in the Syariah enterprise theory which states that social responsibility is a form of human accountability towards Allah in obtaining Allah's bless (legitimacy). 
The disclosure of social responsibility is in accordance with Syariah enterprise theory in Syariah banking which consists of accountability for Allah and Nature [28,29].

H1: the disclosure of sustainability report has significantly positive effect on Syariah banking performance from the religious preservation perspective (diin).

$\mathrm{H} 2$ : the disclosure of sustainability report has significantly positive effect on Syariah banking performance from the assets preservation perspective (maal)

H3: the disclosure of sustainability report has significantly positive effect on Syariah banking performance from the spirit preservation perspective (nafs) and thought ('aql)

H4: the disclosure of sustainability report has significantly positive effect on Syariah banking performance from the descents preservation perspective (nasl)

\section{RESEARCH METHOD}

\subsection{Samples and research data}

This research used qualitative approach in testing the influence of sustainability report disclosure on Syariah banking performance from the perspective of Maqashid Syariah. Sample of this research consist of 12 Islamic commercial banks in Indonesia and 16 Syariah banking in Malaysia who actively report their finance in this research period within 2014-2018. The data were collected from their finance annual report and their sustainability report.

\subsection{Research variable}

Independent variable of this research was the disclosure of sustainability report measured by Syariah value-based measurement by [9], which is standard measurement of sustainability report from GRI 4 which was added by perspective value of Maqashid Syariah. This standard measurement development created 65 standards consist of sustainable general standard, economic sustainability standard, environment sustainability standard and social sustainability report. The score results are divided by standard total, the sustainability report of measurement index is formulated with

$$
\text { SRDI MS }=\frac{D_{S R}}{N}
$$

Explanation:

\section{SRDI : Sustainability Report Disclosure Index} Maqashid Syariah based

$\mathrm{D}_{\mathrm{SR}} \quad$ : Items total disclosed by Syariah bank

$\mathrm{N} \quad$ : Item total of Sustainability report standard

Dependent variable of this research is Syariah bank performance measured by perspective of Maqashid Syariah index (MSI). There are five maqashid index, those are maintaining the religion (diin), maintaining the spirit (nafs), maintaining the thought ('aql), maintaining the wealth (maal) and maintaining the descents (nasb). Those perspective then developed into 18 work measurement ratios [38]

\subsection{Research method}

This research method is beneficial for analyzing the correlation among variables into the data analysis tools easier. Four models used in this research then analyzed by using Generalized Method Moment (GMM), those models which consist of:

$\operatorname{Din}: \alpha+\beta_{1} \mathrm{GSSD}+\beta_{2} \mathrm{EcS}+\beta_{3} \mathrm{EnS}+\beta_{4} \mathrm{SS}+\beta_{5 \mathrm{BA}}+\beta_{6} \mathrm{RR}$

$+\beta_{7} \mathrm{CR}+\varepsilon_{\mathrm{it}}$

Maal $: \alpha+\beta_{1} \mathrm{GSSD}+\beta_{2} \mathrm{EcS}+\beta_{3} \mathrm{EnS}+\beta_{4} \mathrm{SS}+\beta_{5 \mathrm{BA}}+\beta_{6} \mathrm{RR}$

$+\beta_{7} \mathrm{CR}+\varepsilon_{\mathrm{it}}$

$N a f s \&$ 'aql: $\alpha+\beta_{1} \mathrm{GSSD}+\beta_{2} \mathrm{EcS}+\beta_{3} \mathrm{EnS}+\beta_{4} \mathrm{SS}+\beta_{5 \mathrm{~B} A}+$ $\beta_{6} \mathrm{RR}+\beta_{7} \mathrm{CR}+\varepsilon_{\mathrm{it}} \quad(\mathrm{M} 3)$

Nasl : $\alpha+\beta_{1} \mathrm{GSSD}+\beta_{2} \mathrm{EcS}+\beta_{3} \mathrm{EnS}+\beta_{4} \mathrm{SS}+\beta_{5 \mathrm{BA}}+\beta_{6} \mathrm{RR}$

$+\beta_{7} \mathrm{CR}+\varepsilon_{\mathrm{it}}$

Where,

GSSD : General Standards Sustainability Disclosers

EcS : Economic Sustainability

EnS : Environmental Sustaianbility 


$\begin{array}{ll}\text { SS } & \text { : Social Sustainability } \\ \text { UB } & \text { : Bank Age } \\ \text { RR } & \text { : Risk Ratio } \\ \text { CR } & \text { : Capital Ratio } \\ \alpha & : \text { constanta } \\ \beta & : \text { koefisien regresi }\end{array}$

\section{RESULTS AND DISCUSSION}

Table 1 shows the descriptive overview of independent, dependent and control variable of this research. The reporting rate of general sustainability standard by Syariah banking in Indonesia and Malaysia within $2014-2018$ period was $88 \%$, which was obtained from the calculation of $1,77 / 2,00 * 100 \%$. The maximum value was 2.00, which showed that some of the Syariah bank already report the complete or maximum general sustainability standard. The minimum value of economic sustainability was 0.10 and the maximum value was 1.90 . It showed that Syariah bank were not completely report their complete or maximum economic sustainability. The reporting rate of economic sustainability, environment sustainability, and sustainability of each was $40,40 \%$ and $39 \%$. Meanwhile, the sustainability reporting rate total was $49 \%$. This result showed that the sustainability of reporting rate in the Syariah bank is low, based on Maqashid Syariah perspective.

Minimum rate of religious (diin) perspective performance assessment was 0.00. It showed that Syariah banking their financial report did not include their performance ratio indicator for religious (diin) maintenance perspective as interest-free income and publication fees, while in the wealth (maal) perspective performance assessment, the minimum value was negative -1.74. It showed that Syariah bank also experienced loss in operating their business. Minimum value of performance assessment in the spirit, thought and descents (nafs, 'aql, and nasl) preservation were 0.00, which showed that there were several Islamic banks didn't report their assessment ratio indicator of performance perspective in nafs, 'aql and descend. Based on the statistic descriptive result, it showed that the average of bank's age was 16.32 and the standard deviation was 11.80. The minimum value was 4.00 , it means that there were Syariah bank as of 2013 only 4 years old.

After finishing the descriptive statistical testing, panel unit root testing was also done to check the data stationarity. Those steps were the first step in testing the regression of panel data. Muda, et. al., Engle \& Granger $[39,40]$ state that econometric model using non-stationer panel data can cause a problem creating a fake regression. Several research that develop panel unit root test in testing data stationarity was from Levin, et. al., Im et al and Jan, et. al $[41,42,9]$.

In the table II showed that p-value of General Sustainability Disclosures, Diin, Maal, Nafs \& 'aql, Nasl, Bank Age, Risk Ratio and Capital Ratio very significant in $1 \%$, while in the Economic Sustainability, Environmental Sustainability and Social Sustainability pvalue was significant in 5\%. It showed that panel data used in this research did not have unit root and stationer data that normally distributed, so that statistical test can be carried out further. In table III pointed out that in the regression model check result showed that some models didn't meet the classic assumption. Hence, hypothesis test in this research showed that Generalized Method Moment is more suitable to be used.

Table IV pointed out the analysis result of GMM in the 4 research models. Model 1 (diin) measures the impact of sustainability report disclosure on bank performance in the perspective of maintaining religion. Model 2 (maal) measures the impact of sustainability report disclosure on bank performance in the perspective of maintaining wealth. Model 3 (Nasf \& 'aql) measures the impact of sustainability report disclosure on bank performance in the perspective of maintaining spirit and thought. The last, model 4 measures the impact of sustainability report disclosure on bank performance in the perspective of maintaining descents or family. 
Table 1. Descriptive Statistics

\begin{tabular}{|c|c|c|c|c|c|}
\hline Variables & $\mathrm{N}$ & Min & $\operatorname{Max}$ & Mean & $\begin{array}{l}\text { Std. } \\
\text { Dev }\end{array}$ \\
\hline \multicolumn{6}{|l|}{ Independent Variables } \\
\hline General Standard Disclosures (GSD) & 140 & 0,71 & 2,00 & 1,77 & 0,23 \\
\hline Economic Sustainability (EcS) & 140 & 0,10 & 1,90 & 0,76 & 0,42 \\
\hline Environmental Sustainability (EnS) & 140 & 0,00 & 1,33 & 0,27 & 0,40 \\
\hline Social Sustainability (SS) & 140 & 0,05 & 1,55 & 0,52 & 0,33 \\
\hline Total Sustainability & 140 & 1,37 & 6,70 & 3,34 & 1,17 \\
\hline \multicolumn{6}{|l|}{ Dependent Variables } \\
\hline Diin & 140 & 0,00 & 1,09 & 0,79 & 0,29 \\
\hline Maal & 140 & $-1,74$ & 5,84 & 1,39 & 1,11 \\
\hline Nafs \& Aql & 140 & 0,00 & 4,87 & 1,17 & 1,05 \\
\hline Nasl & 140 & 0,00 & 0,97 & 0,00 & 0,00 \\
\hline \multicolumn{6}{|l|}{ Controlled Variables } \\
\hline Bank Age (BA) & 140 & 4,00 & 58,00 & 16,32 & 11,80 \\
\hline Risk Ratio (RR) & 140 & 0,05 & 1,52 & 0,52 & 0,37 \\
\hline Capital Ratio (CR) & 140 & 0,002 & 1,84 & 0,14 & 0,22 \\
\hline
\end{tabular}

Descriptive statistics of overview of independent, dependent and control variable. Reporting rate sustainability disclosure of all bank Islamic in Indonesia and Malaysia during the period 2014-2018.

Table 2. Panel Unit Root Test Result

\begin{tabular}{|c|c|c|c|c|c|}
\hline \multirow[t]{2}{*}{ Series } & \multicolumn{2}{|c|}{ Dickey-Fuller } & \multicolumn{3}{|c|}{ Philips-Perron } \\
\hline & Stat. & Prob. & Stat. & & Prob. \\
\hline GSD & $-1,660496$ & $0,0087 *$ & & $-10,82095$ & $0,0000 * *$ \\
\hline $\mathrm{EcS}$ & $-5,706714$ & $0,0000 * *$ & & $-12,00026$ & $0,0000 * *$ \\
\hline $\mathrm{EnS}$ & $-3,228188$ & $0,0016^{* *}$ & & $-5,264100$ & $0,0000 * *$ \\
\hline SS & $-4,400925$ & $0,0000 * *$ & & $-4,183986$ & $0,0001 *$ \\
\hline TotalSus & $-10,23501$ & $0,0000 * *$ & & $-3,753012$ & $0,0003^{*}$ \\
\hline Diin & $-7,257744$ & $0,0000 * *$ & & $-1,547268$ & $0,0000^{*}$ \\
\hline Maal & $-2,603040$ & $0,0103 *$ & & $-4,725806$ & $0,0000^{*}$ \\
\hline Nafs \& 'aql & $-5,130374$ & $0,0000 *$ & & $-3,827979$ & $0,0002 *$ \\
\hline Nasl & $-3,450266$ & $0,0008 *$ & & $-4,005813$ & $0,0001 *$ \\
\hline BA & $-5,032408$ & $0,0000 *$ & & $-3,874797$ & $0,0002 *$ \\
\hline RR & $-2,698600$ & $0,0078 *$ & & $-4,438018$ & $0,0000 *$ \\
\hline $\mathrm{CP}$ & $-7,009708$ & $0,0000 *$ & & $-7,267693$ & $0,0000^{*}$ \\
\hline
\end{tabular}

The results of panel unit root test of all variabel

*significant at $1 \% *$ significant at $5 \% * * *$ significant at $10 \%$

Tabel 3. Diagnostic Checks

\begin{tabular}{llll}
\hline Parameter & Heteroscedasticity & Serial Correlation & Omitted Vaariables \\
\hline Diin & 0,00 & 0,00 & 0,00 \\
Maal & 0,01 & 0,00 & 0,00 \\
Nasf \& 'Aql & 0,18 & 0,00 & 0,00 \\
Nasl & 0,01 & 0,00 & 0,01
\end{tabular}

The result of diagnostic tests carried out for four regression models 
Table IV pointed out the analysis result of GMM in the 4 research models. Model 1 (diin) measures the impact of sustainability report disclosure on bank performance in the perspective of maintaining religion. Model 2 (maal) measures the impact of sustainability report disclosure on bank performance in the perspective of maintaining wealth. Model 3 (Nasf \& 'aql) measures the impact of sustainability report disclosure on bank performance in the perspective of maintaining spirit and thought. The last, model 4 measures the impact of sustainability report disclosure on bank performance in the perspective of maintaining descents or family.

In model 1 (Diin), p-value of economic sustainability variable was significant in $5 \%$ with score 0.046, social sustainability variable was found significantly in $1 \%$, with score 0.007 , and debt ratio control variable was found significantly in 0.002 . This result explained that economic, social, and debt ratio sustainability were significantly having positive impact on Syariah bank performance in maintaining religion perspective. It means that sustainability report disclosure increases the Syariah bank performance in maintaining religion perspective. This finding supports Julia \& Kasim and Hudaefi \& Noordin [43,38] research' and approve $\mathrm{H} 1 \mathrm{of}$ this research. While in environment and bank's age sustainability variable, it was found that $p$-value significant with a negative coefficient value. This result shows that both of variable negatively impact on bank performance in diin perspective. R2 in model 1 was 0.56 , which mean that $56 \%$ of the model was explained by independent variable.

This research result is consistent with Syariah Enterprise Theory in Mulawarman [27] that said implementation of accountability 'abdAllah in syariah business can be welfare distributions. The distributions are halal syariah and riba-free. This result is different from Mergaliyey's study [44] that found about indicators of Muslim population, CEO duality, Syariah Supervisory Board, and variables of leverage positively influencing the disclosure of maqashid performance. CEO duality and DPS are the indicators or parameters in standard measurement of general sustainability. That being said, this research result does not bring any influences to syariah bank performance in diin perspective.

In model 2 (Maal), the economic sustainability variable $p$-value was found significant on $1 \%$ by 0,001 marks. This implies that sustainability economy disclosure significantly positively influencing on perspective bank performance maintaining wealth. Meanwhile, a significant control variable with a negative constant value is the capital ratio. It marks that as smaller the capital ratio value, the bigger the bank performance of maal perspective and vice versa. If the value of R2 on model 2 (Maal) is 0,42 meaning $42 \%$ of the model is explained by the independent variable. Therefore, it is consistent with the Syariah Enterprise Theory that states one of the horizontal accountability forms to customers and employees is a report of zakat funds and gardhul hassan also the finance of profit and loss sharing [28]. That being the case, accountability can be manifested in a responsible report to increase the sustainability of the company. This finding supports the result of Jan's research, Platonova et al, and Ameer \& Otham $[9,15,45]$. Their results show that the sustainability report has a positive relationship with financial performance. Thus, this $\mathrm{H} 2$ research is accepted.

Model 3 (Nafs and 'Aql) is a model research that measures sustainability report of perspective performance of bank of life and mind maintenance. According to Rauf and Hudaefi \& Noordin [36,38] the form of life and mind maintenance in context of syariah bank in an intelectual increasing through education and practice on employees and education scholarship and study. Based on the p-value table, general sustainability standard and social sustainability variable in Model 3 (Nafs and 'Aal) was found significant on $1 \%$ on 0,007 and 0,003 value. Meanwhile, bank control age variable was found significant on $1 \%$ with a negative coefisien value. Analysis result shows that the standard variable of general sustainability and social sustainability affecting positively and supporting Dusuki \& Abdullah, Hudaefi \& Noordin and Julia \& Kasim [23,38,43]. Therefore, this $\mathrm{H} 3$ research is accepted.

According to Dusuki \& Abdullah [23] it was explained that on the first level of par amide that is implied on CSR, which says the manager is expected to manage to keep and take care of the essential need that is important; such as religion, life, intelligence, descendant, and property. On the second level, the company is helpful to eliminate obstacles that probably is not harmful to the life of normal order. On the highest level, cooperation is expected to be able to do its social responsibility by involving in an activity or program that can help the increase and achievement of perfect public life. The examples are giving back to the poor and offering scholarship to the students in need. It is in accordance with Syariah Enterprise Theory, that responsibility to Allah as a vertical accountability by giving zakat, alms, and infaq according to His command for getting merit in reward. In addition, it is to use the fund for social needs, thus it can keep our life and mind to always be able to give the best. 
Table 4. Impact of sustainability report on bank performance perspective of maqashid syariah (GMM)

\begin{tabular}{|c|c|c|c|c|c|c|c|c|}
\hline \multirow[t]{2}{*}{ Variabel } & \multicolumn{2}{|c|}{$\begin{array}{c}\text { Model } 1 \\
\text { Diin }\left(\mathrm{R}^{2}=0,56\right)\end{array}$} & \multicolumn{2}{|c|}{$\begin{array}{c}\text { Model } 2 \\
\text { Maal }\left(\mathrm{R}^{2}=0,42\right)\end{array}$} & \multicolumn{2}{|c|}{$\begin{array}{c}\text { Model 3 } \\
\text { Nafs \& 'aql }\left(\mathrm{R}^{2}=0,40\right)\end{array}$} & \multicolumn{2}{|c|}{$\begin{array}{c}\text { Model } 4 \\
\text { Nasl }\left(\mathrm{R}^{2}=0,37\right)\end{array}$} \\
\hline & Coef. & Prob. & Coef. & Prob. & Coef. & Prob & Coef. & Prob. \\
\hline _cons & 0,854 & 0,000 & 0,069 & 0,922 & $-0,567$ & 0,404 & $-0,003$ & 0,507 \\
\hline GSD & $-0,062$ & 0,465 & 0,536 & 0,702 & 0,978 & $0,007 * * *$ & 0,003 & 0,204 \\
\hline $\mathrm{EcS}$ & 0,155 & $0,046^{* *}$ & 1,093 & $0,001 * *$ & $-0,107$ & 0,743 & $-0,000$ & 0,839 \\
\hline EnS & $-0,190$ & 0,018 & $-0,649$ & 0,363 & $-0,078$ & 0,815 & 0,002 & 0,390 \\
\hline SS & 0,300 & $0,007 * * *$ & 0,520 & 0,291 & 1,408 & $0,003 * * *$ & 0,009 & $0,005 * * *$ \\
\hline BA & $-0,016$ & 0,000 & $-0,010$ & 0,152 & $-0,019$ & 0,005 & $-0,000$ & 0,000 \\
\hline $\mathrm{RR}$ & 0,205 & $0,002 * * *$ & $-0,477$ & 0,122 & $-0,489$ & 0,084 & $-0,000$ & 0,812 \\
\hline $\mathrm{CR}$ & $-0,142$ & 0,080 & $-1,052$ & 0,003 & $-0,434$ & 0,206 & 0,001 & 0,512 \\
\hline
\end{tabular}

*significant at $1 \% *$ significant at $5 \% * * *$ significant at $10 \%$

Model 4 (Nasl) is perspective syariah bank keeping the descendant or family. In the model 4 there is just the social sustainability variable that shows significant $\mathrm{p}$ value that is 0,00 . Meanwhile the control variable that is significant with negative coefficient value is bank age variable with 0,000 value. This result supports Julia \& Kasim's (2019) research that found green banking program is aim to conserve the environment by conducting action and transaction of economy environment. Thus the future generation can benefit better environment. This result shows that the fourth hypothesis is accepted.

Conserve the environment for the future generation is a step of preserving the descendant. It also means to keep ecosystem or the nature to be balance because if there is a natural damage causing disaster, it can damage the descendant or the future generation. It is in accordance with the Syariah Enterprise Theory concept that says the responsibility is not just for the importance, but also Allah, human beings, and nature [28].

Syariah Enterprise Theory places nature as the third stakeholder, because nature is the one contributing for human beings life [46,28]. The company excise physically because it is built on earth, uses its energy, produces using the material of natural resources, pollution prevention for the life of human being so that the descendant and the future generation are in keep.

\section{CONCLUSIONS}

This research evaluates the impact of sustainability report on syariah bank performance in Indonesia and Malaysia of 2014-2018 period. In accordance with the purpose, this research used Generalized Method Moment (GMM) to analyze the relation of independent and dependent variables. The result shows that the disclosure of sustainability report has positive significant impact on the perspective bank of maqashid syariah performance as shown on table III.

The result of statistical analysis of Model 1 shows that economy sustainability, social sustainability, and debt control variable impact positively and significantly to the perspective bank performance that maintain religious (diin). Meanwhile, the environment sustainability variable and age bank variable impact negatively and significantly on $1 \%$. It supports the $[43,38]$ researches who found that syariah bank is foremost in conserving religion.

In Model 2 (Maal) found that sustainability economy variable impacts positively and significantly on 0,001 . This result supports $[45,15,9]$ researches that found the sustainability report impacted positively on company performance. The control variable of capital ratio impacts negatively and significantly. It is different from the research conducted by Jan, et.al [9]. It means that debt management also impacts the finance bank performance. In addition, Model 3 (Nasf \& 'Aql) which is the perspective bank of life and mind maintenance found that standard variable of general sustainability and social sustainability impacts positively and significantly. It signs that the sustainability report is one of the horizontal accountabilities. This result supports the Syariah Enterprise Theory as one of the horizontal accountabilities which is responsibility to human beings (employees, people, and society). 
The result of the statistical analysis of Model 4 (Nasl) shows that only the social sustainability variable impacts positively and significantly on the performance of the descendant and family maintenances. It also shows that the control variable of age bank impacts negatively and significantly on $1 \%$. It shows that sustainability report disclosure is also one of the company's accountability to the human being and nature. However, this result is only the standard variable of sustainability general that only impacts positively. The consistency with Syariah Enterprise Theory and also supports the Julia \& Kasim's research [43]. Their research found that syariah bank in its business activity also imply the Islam purpose of spreading rahmat or affection to the nature by keeping and conserve nature for today and future generations. However, in this research result there is only standard variable of general sustainability which impacts positively.

Based on the discussion and limitation of research, suggestion to the future study can add the research sample and period report because this research only used syariah bank in Indonesia with 5 years period report as the samples. Researchers can also add sample study of syariah bank in other countries. The next research can also discuss more about control variable use because the result of this research shows that control variable contribution is not really big.

\section{REFERENCES}

[1] M. I. Syairozi, Pengungkapan CSR Pada Perusahaan Manufaktur Dan Perbankan, Magelang : Tidar Media, 2019.

[2] J. R. Jambeck, R. Geyer, C. Wilcox , T. R. Siegler , M. Perryman, A. Andrady, R. Narayan and K. L. Law , "Plastic Waste Inputs From Land Into the Ocean," Science, p. Vol. 347 ISSUE 6223, 2015.

[3] L. T. Panjaitan, Bank Ramah Lingkungan Panduan Keberlanjutan (Sustainability), Jakarta: Penerbar Plus, 2015.

[4] M. D. Hadad and I. Maftuchah, Sustainable Financing Industri Jasa Keuangan Dalam Pembiayaan Berkelanjutan, Jakarta: PT. Elex Media Komputindo, 2015.

[5] A. Fauzi, Teknik Analisis Keberlanjutan, Jakarta: Gramedia Pustaka Utama, 2019.

[6] X. Li , H. Yin and J. Liu, "Is China's Banking Industry Embracing Sustainable Investment?," Applied Economics Letters, 2017.

[7] X. Long and X. Ji, "Economic Growth Quality, Environmental Sustainability, and Social Welfarein China-Provincial Assessment Based on Genuine Progress Indicator (GPI)," Ecological Economics, pp. Vol. 159 hal. 157-179, 2019.
[8] M. Jeucken, "Banking and Sustainability; Slow starters are gaining pace," Ethical Corporation Magazine, pp. 11, 44-48, 2002.

[9] A. Jan, M. Marimuthu and M. B. Pisol, "The Nexus of Sustainability Practices and Financial Performance; From the Perspective of Islamic Banking," Journal of Cleaner Production, pp. S0959-6526(19)31295-8, 2019.

[10] R. Care, Suatainable Banking Issues and Challenges, Cham, Switzerland: Springer Nature, 2018.

[11] P. Sapienza and L. Zingales, "A Trust Crisis," International Review of Finance, pp. pp. 123-131, 2012.

[12] Gustani, "Analisis Tingkat Pengungkapan Kinerja Sosial Bank Syariah Berdasarkan Islamic Social Reporting Index," Depok, 2013.

[13] H. Nobanee and N. Ellili, "Corporate sustainability disclosure in annual report: Evidence from UAE banks: Islamic versus conventional," Renewable and sustainability energy reviews, pp. Vol. 55 Pages 1336-1341, 2016.

[14] I. Meutia and D. Febrianti, "Islamic Social Reporting in Islamic Banking: Stakeholders Theory Perspective," SHS Web of Conferences, p. 34, 2017.

[15] E. Platonova, M. Asutay, R. Dixon and S. Mohammad, "The Impact of Corporate Social Responsibility Disclosure on Financial Performance: Evidence From the GCC Islamic Banking Sector," J Bus Ethics, 2016.

[16] R. Iskandar, "Islamic social reporting, kinerja keuangan, manajemen laba. Bukti empiris pada bank syariah di wilayah GCC," 2019.

[17] N. Adib and S. N. A. Khalid , "Performance Measurement System in Islamic Bank: Some Issues and Considerations," Jurnal Akuntansi Multiparadigma, p. Vol. 1 No 3, 2010.

[18] A. M. A. Eljelly and A. A. Elobeed, "Performance Indicators of Banks in a total Islamic Banking System: the case of sudan," 2014.

[19] S. A. Ali, S. Azam, A. Razi and U. Aslam, "Determinants of Profitabilitas of Islamic Bank. A Case Study of Pakistan," Interdisciplinary Journal of Contemporary Research in Business, pp. Vol. 2 No. 11 p. 86-99, 2012.

[20] L. T. Al-Kayed , S. R. S. M. Zain and J. Duasa , "The Relationship Between Capital Structure and Performance of Islamic Banks," Journal of Islamic Accounting and Business Research, pp. Vol. 5, Iss 2 pp. 126-141, 2014.

[21] H. Bedoui and W. Mansour, "Islamic Banks Performance and Maqasid Shari'ah," Paper presented to the 9th Asia-Pacific Economic Association Conference, pp. July 27-28, OsakaJapan, 2013. 
[22] M. U. Chapra, The Future of Economics: An Islamic Perspective., Gema Insani Press, 2001.

[23] A. W. Dusuki and N. I. Abdullah, "Maqasid alShari'ah, Maslahah, and Corporate Social Responsibility," The American Journal of Islamic Social Sciences, pp. Vol 24, No. 1 hlm. 25-45, 2007.

[24] N. L. S. G. Maji, "Corporate Sustainability Reporting Practices in India: Myth or Reality?," Social Responsibility Journal, pp. Vol. 12 Iss 4 pp, 2016.

[25] I. Triyuwono, Perspektif, Metodelogi, dan Teori Akuntansi Syariah, Jakarta: PT Raja Grafindo Persada, 2006.

[26] I. Triyuwono, "Konsekuensi Penggunakan Entity Theory Sebagai Konsep Dasar Standar Akuntansi Perbankan Syariah," JAAI, p. Volume 7 No. 1, 2003.

[27] A. D. Mulawarman, Akuntansi Syariah (Teori, Konsep, dan Laporan Keuangan), Jakarta: EPublishing Company, 2009.

[28] I. Meutia, "Shari'ah Enterprise Theory Sebagai Dasar Pengungkapan Tanggungjawab Sosial Bank Syariah," Malang, 2009.

[29] F. S. Zakiy, "Sharia Enterprise Theory sebagai Pilar Pengungkapan Corporate Social Responsibility di Perbankan Syariah," Universitas Islam Negeri Maulana Malik Ibrahim, Malang, 2015.

[30] A. D. Mulawarman, I. Triyuwono and U. Ludigdo, "Rekonstruksi Teknologi Integralistik Akuntansi Syari'ah: Shari'ate Value Added Statement," Jurnal Akuntansi dan Keuangan Indonesia, pp. Vol. 4, hal. 1-24, 2007.

[31] J. Auda, Maqasid Al-Shariah as Philosophy of Islamic Law. A systems Approach, Washington : The International Institue of Islamic Thought, 2007.

[32] A. A. Shinkafi, N. A. Ali and M. Choundhury, "Contemporary Islamic Economic Studies on Mqashid Shari'ah: A Systematic Literature Review," Humanomics, 2017.

[33] G. Shidiq, "Teori Maqashid Al-Syariah Dalam Hukum Islam," pp. vol. XLIV 117-130, 2009.

[34] D. Naja , Bekal Bankir Syariah, Ponorogo: Uwais Inspirasi Indonesia, 2019.

[35] S. S. Ali, Towards A Maqasid al-Shari'ah Index of Socio-Economic Development Theory and Aplication, Palgrave Macmillan , 2019.

[36] I. F. A. Rauf, Defining Measuring and Indexing Islamic Contemporary Statehood Muslim States, London: Palgrave Macmillan, 2015.

[37] A. Sarwat, Maqashid Syariah, Jakarta: Rumah Fiqh Publishing, 2019.

[38] F. A. Hudaefi and K. Noordin , "Harmonizing and constructing an integrated maqashid al syariah index for measuring the performance of islamic banks," ISRA International Journal of Islamic Finance, 2019.

[39] M. Muda , A. Shaharuddin and A. Embaya , "Comparative analysis pf profitability determinants of domestic and foreign Islamic banks in Malaysia," International Journal of Economics and Financial Issues, Vols. Vol. 3, No. 3, pp. pp. 559-569, 2013.

[40] R. F. Engle and C. W. Granger , "Co-integration and error correction; represntation, estimation and testing," Econometrica; journal of the Econometric Society, vol. Vol. 55 No. 2, pp. pp. 251-276, 1987.

[41] A. Levin , C. F. Lin and C.-S. J. Chu , "Unit root tets ini panael data; asymptotic and finite-sampel properties," Journal of econometrics, vol. Volume 108, no. 1, pp. pages 1-24, 2002.

[42] K. S. Im, M. H. Pesaran and Y. Shin , "Testing for unit roots in heterogeneous panels," Journal of econometrics, vol. Volume 115, no. Issue 1, pp. Pages 53-74, 2003.

[43] T. Julia and S. Kassim, "Exploring green banking performance of Islamic bank vs conventional banks in Bangladesh based on Maqasid Shariah framework," Journal of Islamic Marketing, 2019.

[44] A. Mergaliyev, M. Asutay, A. Avdukic and Y. Karbhari, "Higher Ethical Objective (Maqasid alshariah) Augmented Framework for Islamic Banks: Assessing Ethical Performance and Exploring Its Determinants," Jornal of Business Ethics, 2019.

[45] R. Ameer and R. Othman , "Sustainability Practices and Corporate Financial Performance: A Study Based on the Top Global Corporations," J Bus Ethics, pp. 108: 61-79, 2011.

[46] Samsiyah , Y. Sambharakhresna and N. Kompyurini, "Kajian Implementasi Corporate Social Responsibility Perbankan Syariah Ditinjau dari Shariah Enterprise Theory pada PT. BPR Syariah Bhakti Sumekar Cabang Pamekasan," Jurnal InFestasi, pp. Vol. 9 No. 1 Hal. 47-60, 2013. 